International Journal of Instruction
e-ISSN: $1308-1470 \bullet$ www.e-iji.net

\title{
Positive Psychology in the Class: The Effectiveness of a Teaching Method Based on Subjective Well-Being and Engagement Increasing Activities
}

\author{
Ali Eryılmaz \\ Assoc. Prof. Department of Psychological Counseling and Guidance, Eskisehir \\ Osmangazi University, Eskişehir, Turkey,erali76@hotmail.com
}

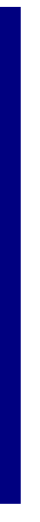

The aim of the present study is investigate that the effectiveness of a teaching method which is based on subjective well-being increasing activities and engagement increasing activities, has been developed for university students in the present study. The method of the present study is a mixed method. Thus, the most important feature of it has been considered experimental method that includes pretest, post-test and follows up design with experimental and control groups. Also, qualitative method has been conducted in the present study. 72 university students (14 males and 22 females in the experimental group; 10 male and 26 female in the control group) participated in this study. The Positive and Negative Affect scale, Engagement Scales, academic achievement tests were used to collect data. The study findings suggest that the levels of subjective well-being, engagement, learning, academic achievement of students may be increased through using this teaching method.

Key Words: University students, engagement, subjective well-being, teaching, students

\section{INTRODUCTION}

Since, positive teaching practices and method increases not only students' learning and academic achievement but also students' subjective well-being, some researchers suggest that positive teaching practices and method should be developed (Loveless, 2006). The most important educational settings where positive teaching practices and methods should be developed and implemented are universities. Development of positive teaching practices and method may contribute to achieve learning potential, have positive attitudes higher education and future employment for university students (Nilson, 2010). The most important feature of a positive teaching method can be engagement and subjective well-being increasing activities.

Subjective Well-Being, Increasing of Subjective Well-Being and Teaching Process Subjective well-being has been considered as a positive aspect of mental health (Hefferon \& Boniwell, 2010). Subjective well-being has often been described in terms of positive and negative affection and life satisfaction (Diener, 1984). If individuals have more experiences that give pleasure and satisfaction, and also fewer unpleasant experiences they are considered to have more subjective well-being (Eryllmaz, 2012).

DOI: $10.12973 / \mathrm{iji} .2015 .822 \mathrm{a}$ 
Purposeful activities have been considered as subjective well-being increasing strategies (Lyubomirsky, Sheldon \& Schkade, 2005). Subjective well-being increasing strategies have been studied by many researchers (Buss, 2000; Eryllmaz, 2012; Fordyce, 1983; Lyubomirsky, Sheldon \& Schkade, 2005). In literature, many activities have been developed in accordance with subjective well-being increasing strategies (Hefferon \& Boniwell, 2010) for instance, activities involving things that made me happy in the past include: gratitude, thankfulness, increasing self-esteem, social support, happinessoriented behaviours, flow, goal setting (Fordyce, 1983; Lyubomirsky, Sheldon \& Schkade, 2005).

Skinner, Furrer, Marchand and Kinderman (2008) conclude that the affection dimension of subjective well-being is an important driver of students' engagement in learning activities. In educational settings, subjective well-being of students was found to be related to satisfaction with school, teacher support and intelligence (Ash \& Huebner, 2001; Baker, 1998). Moreover, it has been reported that there were positive relationship between students' subjective well-being and academic achievement (Cheng \& Furnham, 2002). Furthermore, some theories focus on students' subjective well-being, academic achievement and learning in the teaching and learning process. For instance, according to Flow Theory, students are subjectively well when they are in a state of flow, and also they have improved their academic achievement when flow experiences are included in the teaching method (Johnson, 2001). Likewise, Self Determination Theory indicates that the level of students' subjective well-being increases when they satisfy their psychological needs, such as competence, relatedness and autonomy in the class (Deci \& Ryan, 2002). Although these studies and theories indicate that level of students' subjective well-being should be increased in class settings, no previous studies have been considered to integrate subjective well-being increasing activities within a teaching method.

\section{Engagement and Learning}

Engagement is the most important side of learning. Researchers have investigated engagement in a variety of contexts such as school, class academic and social life (Reschly \& Christenson, 2006). Besides, there have been different definitions of engagement in the literature. For instance, student engagement has been defined as "participating in the activities offered as part of the school program" by Natriello (1984, p-14). Beside this general definition, engagement in the class has been defined as "constructive, enthusiastic, willing, emotionally positive and cognitively focused participation with learning activities in the classroom" by Skinner and Pitzer (2012, p22). Engagement in the classroom consists of three indicators: behavioural, cognitive and emotional (Reschly \& Christenson, 2006; Skinner \& Pitzer, 2012). Students' engagement have played important roles for positive daily experience, development of academic abilities, short and long term learning according to empirical evidence: (Reschly \& Christenson, 2006; Skinner \& Pitzer, 2012). Whereas, experiencing drop out, academic failure, boredom, passivity, absenteeism, aimlessness, avoidance, apathy has been found to be associated strongly with low level students' engagement (Martin, 2003). Additionally, some engagement activities that are used in the class such as: 
think-pair-share, minute papers, writing, brainstorming, games, debates, group work, subject summaries, research or independent study, technology use, case studies, simulations, role-playing, challenging questions, have been developed to engage university students (Nilson, 2010).

One of the major goals of education is learning (Scheerens \& Bosker, 1997). The way of achieving this goal has been reached by means of different teaching methods. For instance, when teachers have used such different teaching methods as giving feedback on time, effective classroom management, building positive class atmosphere, using construct maps, asking questions and presenting structured knowledge, students' academic achievement and learning will increase. Classical teaching methods based on teacher lecturing do not contribute to increasing their engagement, learning and subjective well-being, since it uses maladaptive teaching features such as overwhelming homework and full class schedules, lack of interest in student attendance, engagement and affection, lack of caring about students' work, lack of belonging (Skinner \& Pitzer, 2012). We need some teaching methods that give an opportunity to engage a whole large class of 30-45 students.

Subjective well-being is a major area of interest within the field of positive psychology, and has also been studied by many researchers. For instance, Seligman (2002) identifies that engaged life and pleasant life are the most important indicators of individuals' subjective well-being. Schools can be considered as the most important domain for experiencing engagement and pleasure. Thus, students should have engaged life and pleasant life to increase their subjective well-being levels, since they spend most of their time in it (Davis, Kruczek \& McIntosh, 2006). Moreover, some researcher argues that students should experience subjective well-being while they have been learning in the class to get high levels of academic achievement, to build the capacity, to increase the ability, and to broaden the perspective (Loveless, 2006). Although extensive research has been carried out on students' subjective well-being in the school and classroom (Ash \& Huebner, 2001; Baker, 1998), little attention has been paid to develop a teaching method based on engagement (Nilson, 2010) and subjective well-being increasing activities. Consequently, the aim of the present study is to develop a teaching method which is based on subjective well-being increasing activities and behavioural, cognitive, and also emotional engagement increasing activities.

\section{METHOD}

\section{Research Design}

The present study has been considered as a mixed method, which includes pre- and posttest and follow-up design with experimental and control groups. The independent variables for the present study are applications of the subjective well-being-increasing activities and engagement increasing activities through teaching methods; while the dependent variables are the levels of academic achievement and behavioural, cognitive, emotional engagement, and also positive and negative affections of the participants.

Some subjective well-being and engagement increasing activities were implemented during the teaching process and the effects of these activities were measured in both 
short term and long term. As a part of the short-term effects, the Positive and Negative Affect scale, Engagement Scales were used both before and after the activities which were implemented. As a part of the long term effects of activities, Positive and Negative Affect scales and academic achievement tests that were developed by the teacher of the lesson were implemented. In addition to these, 36 participants in each of the experimental and control groups were administered a follow-up study after two months following the experimental procedure. The Wilcoxon Signed Rank and Mann Whitney $\mathrm{U}$ Test were used in order to assess the effectiveness of the teaching method in this study. Moreover, further qualitative data were obtained by asking the open-ended question, "What are your opinions and feelings about the positive side of teaching process; what are your opinions and feelings about the negative side of teaching process, and also what your suggestions for future implementations are?" The responses given to this question were then analysed through the sentence-based content analysis method.

There has been some scientific basis for the teaching method that developed in the present study. First of all, this teaching method is based on increasing level of subjective well-being of the students. Since, it is concluded that if students' level of subjective well-being increase, their perspectives and capacities will broaden (Hefferon \& Boniwell, 2010). Thus, eight subjective well-being increasing activities, which were developed according to subjective well-being literature, were implemented in the present study. The features of these activities are: "Five things that made me happy in the past" activity: In this activity, the students are asked to write down five things that had made them happy sometime in the past and the reasons for them. "Gratitude" activity: In this activity, the students are asked to mention five people for whom they have felt gratitude with their particular reasons. Next, they are asked to choose one of these people and write a letter of gratitude to him or her. "Thankfulness" activity: In this activity, the students are asked to relate five things for which they feel obliged to thank with their reasons. "The positive perception of myself" activity: In this activity, the students are asked to express their strength, the features they are proud of, and their achievements. "Those supporting me in my life" activity: In this activity, the students are asked to write down the names of those who support them in life, as well as their feelings and thoughts about this support. "Happiness-oriented behaviours" activity: In this activity, the students are asked to cite the name of one poem, one film, one eloquent statement and one joke that they derived pleasure from sometime in their lives. " $M y$ flow list" activity: In this activity, the students are offered a list of 16 different flow activities which they are supposed to put in order in a way that the one making them happiest is at the top. "My future goals" activity: In this activity, the students are asked to set their goals pertaining to carrier-personal development, interpersonal relationships, health, and contribution to society and spirituality. Secondly, the teaching method increases levels of student engagement, since, it is concluded that if students' level of engagement increase, their positive daily experience, academic abilities and achievements, short and long term learning will also increase (Reschly \& Christenson, 2006; Skinner \& Pitzer, 2012). Thus, some engagement increasing activities such as constructing maps, think-pair-share, minute papers, writing, brainstorming, debates, group work, subject summaries, research or independent study, technology using, case 
studies, challenging questions and questions preparing for class, integration of the new knowledge with old one, imagination of the topics, connecting the topics with the real life and processing of the information which were developed according to engagement literature were implemented in the present study (Nilson, 2010; Reschly \& Christenson, 2006; Skinner \& Pitzer, 2012). These activities should be implemented in a systematic way during the whole class session. In order to establish this systematic application, we need a standard form. Thus, a constructed worksheet which includes these activities was prepared. The features of the constructed worksheet and the other activities are presented blow. Engagement Worksheet: In order to increase students' behavioural, cognitive and emotional engagement, the teacher has already prepared a standard worksheet which students should bring in for every daily lesson and complete during the class session. There are nine such parts including: a summary of the subject, positive psychology activity (subjective well-being increasing activities), first question writing, meaning of subject in the daily life, examples of my life related to the subject, second question writing, what we learnt by the end of the day, how I can use things that I learnt in my own life, and how I can use things that I learnt in my career.

\section{Experimental Process}

Participants of the present study were undergraduate students in the psychological counseling and guidance program at a state university in Turkey. The teaching method was implemented in the lesson of "human relationships and communication". The book which is named Understanding Close Relationships written by Hendirick (2003) has been used during the implementation process as the main source. In this university, teaching term lasts 14 weeks, with two weeks reserved for the exams. Regarding this limited time, the teacher made a time scale for the implementation. Thus, in the implementation process, two weeks were reserved for pre- and post-tests, measure and evaluations, and two weeks reserved for feedback of application homework. Thus, the remaining eight weeks were reserved for the main implication process. Hence, eight subjects in total were lectured, including: importance of relationships, attraction and relationship development, friendship and social support, romantic love, relational sexuality, communication and relational maintenance, conflict and abuse, breakup, divorce, and bereavement. The reason why this lesson is chosen is that the researcher in the present study was the lecturer of it.

There were two forty-five-student classes in the program. These two classes were randomly assigned to either the experimental or the control group. Before the experimental process, the researcher wanted to match the experimental and control groups in that students' general engagement levels of behavioural, cognitive and emotional. For that purpose, the General Engagement Scale was implemented, and it was found that there were no differences between groups. Afterwards, the researcher informed experimental participants of such key elements of the lesson as introducing students to the teaching method, main sources, requirements, attendance policy, and lesson outline, grading in the first class session. The researcher also informed participants in the control group about the method of teaching that is the traditional method of teaching (teacher dominated interaction). Then, pre-tests implementations 
were done. Both students in the experimental and control group were measured in that experiencing positive and negative affection, students' behavioral, emotional and cognitive engagement for just only this specific lesson at the end of the second and seventh weeks. However, during the school hours, teacher continued with the regular curricula of human relationships and communication lesson which were to impart and to discuss issues related to the human relationships and communication with the students in the control group. The control group did not participate in any subjective well-being increasing activities and engagement activities as utilized in the experimental group.

After the midterm exam, some homework was given to students who were assigned in the experimental and control group. The students into both groups were asked to prepare four group counselling program plans for students (two of them about conflict resolution, and about parents and friends) and for romantic partners (one of them conflict resolution, and one of them relationship satisfaction about romantic relationships). While they were preparing these plans, they would ask make a power point presentation about the topic. During the teaching process, the students' affections were measured before and after subjective well-being activities were implemented every week. Furthermore, the post-tests were implemented in the ninth week. The midterm exam was applied after four weeks; whereas the final exam was applied after eight weeks. In addition to these exams, qualitative questions were asked in the ninth week, and also the midterm exam was implemented as a follow-up study after two months from the final exam.The students in experimental group were asked to bring their engagement worksheet every week. The students filled these in during the lessons. The teacher evaluated this form and gave a mark weekly. Then, the teacher gave these forms to students at the beginning of the following lesson. Then, the students were supposed to write a fair copy of them, and to submit them electronically before the next lesson. Additionally, the teacher draws a construct map on the board about every daily subject. Teaching method were implemented four hours a week during the eight weeks. The total lesson hour was fifty minutes, and the break time was ten minutes. The students filled the engagement worksheets by teacher's directions. In addition to filling worksheet, the teacher also lectured twenty-five minutes in every lesson hour. Special standard times were given for students to fill the every parts of worksheet parts in the class. These are presented below:

The first hour of a four hours class: All students are required to write a summary of the subject in ten minutes, to complete a positive psychology activity in ten minutes, and to write a first question in five minutes. The teacher lectured for twenty-five minutes in total. The second hour of a four class: All students are required to relate the subject to daily life in ten minutes, to write first question in five minutes, and to give an example related to their life in ten minutes. The teacher lectured for twenty-five minutes in total. The third hour of a four class: All students are required to do positive psychology activity in ten minutes, to write what they learnt by the end of the day in fifteen minutes. The teacher lectured for twenty-five minutes in total. The fourth hour of a four class:: All students are required to write how they can use things that they learnt in their own life in ten minutes and to write how they can use things that they learnt in their career as 
a counsellor. The teacher summarized the subject and answered the questions of students in twenty-five minutes.

\section{Study Groups}

Some inclusion and exclusion criteria were determined in the present study. Students in the present study have the legal right be absent from school for up to three weeks. Thus, students who fully participated in classes during the eight weeks were included in the experimental and control group. Nine students were excluded from the experimental group, since they were absent from school at least one week due to such reasons as health problems, personal and family problems. Similarly, eight students were excluded from the control group for the same reasons. One student was also randomly excluded from the control group due to group match. As a result, totally 72 students who were not absent from the school during the eight weeks were included in both the control (36) and the experimental groups (36). Control Group: Participants of control group comprised 36 university students aged between 19 and 21 years of whom 14 males and 22 females at second grade. Their mean age was 20.42 and standard deviation was 1.25. Experimental Group: 36 graduate students (10 male and 26 female) aged between 19 and 21 years participated as a members of control group. Their mean age was 20.05 , and also standard deviation was 1.17 .

\section{Instruments}

Personal Information Form: To determine demographic features of the participants, a personal information form was devised, seeking such information as age, gender etc. Positive - Negative Affect Scale (PANAS): PANAS is a 20-item two dimensional measure of individuals' evaluation of his or her emotions they experienced. Positive and negative affect scale requires respondents to rate items on a 5-point Likert-type scale ranging from 1 (strongly disagree) to 5 (strongly agree). This scale was developed by Watson and colleagues (1988). It was adapted to the Turkish language by Gençöz (2000). The Cronbach's alpha coefficients of $0.83-0.86$ for the positive and negative affect measure. Engagement Scale for a Specific Lesson: Engagement Scale for a Specific Lesson is a 15-item three dimensional measure evaluation of students' cognitive, behavioural and emotional engagement they participate in the specific lesson. It was developed by Eryllmaz (2014). This scale requires respondents to rate items on a 4-point Likert-type scale ranging from 1 (strongly disagree) to 4 (strongly agree). The Cronbach's alpha coefficients of were 0.88-0.90-0.93 for student's cognitive, behavioural and emotional engagement measure. Engagement Scale in General: Engagement Scale in General is a 15-item three dimensional measure evaluation of students' cognitive, behavioural and emotional engagement that students exhibit them in all lessons in the school. It was also developed by Eryllmaz (2014). This scale requires respondents to rate items on a 4-point Likert-type scale ranging from 1 (strongly disagree) to 4 (strongly agree). The Cronbach's alpha coefficients of were $0.84-0.86-$ 0.84 for students' cognitive, behavioural and emotional engagement measure.

Midterm Exam: This exam which is a teacher-made test is designed to measure students' learning during the four weeks. It consists of twenty test questions. Additionally, 
midterm exam was also used for the follow-up study. Final Exam: This exam which is a teacher-made test is designed to measure learning of students during the eight weeks. It consists of twenty five test questions. Application Exam: Students were asked to prepare four group counselling program plans for students. Four criteria which were: order, focus, content and supporting with visuals were determined for the evaluation of this homework. In the evaluation process, the assistant of this lesson and also the teacher evaluated the homework based on those criteria and scored each student out of 100 . Then, the assistant's and the teacher's marks were added and divided into two. The results were used as homework marks. Qualitative Assessments Form: This was used in order to enrich qualitative data and included four open-ended questions.

\section{FINDINGS}

\section{Findings about matching experimental and control groups}

In order to match the groups, positive and negative affect scales which display general affection of participants and general engagement scale were used. According to the Mann Whitney $U$ test results, generally there was not a significant difference between the groups in terms of emotional engagement $(U=588.500, p=0,501 ; p>0.05)$, behavioural engagement ( $\mathrm{U}=611.000, \mathrm{p}=0,675 ; \mathrm{p}>0.05)$, cognitive engagement $(\mathrm{U}=589.500, \mathrm{p}=0,508 ; \mathrm{p}>0.05)$, positive affection $(\mathrm{U}=639.500, \mathrm{p}=0,835 ; \mathrm{p}>0.05)$ and negative affection ( $\mathrm{U}=647.000, \mathrm{p}=0,991 ; \mathrm{p}>0.05)$.

\section{Findings related to the effects of the activities implemented in the experimental process}

\section{Effects of the engagement activities implemented in the experimental process}

Nine engagement activities which were included in the engagement worksheet were used in the experimental process. In the experimental process, students' levels of behavioral, cognitive and emotional engagement, and also the positive-negative affect were measured at two points during the lesson. The results were presented in Table-1. According to the Mann Whitney $U$ test results of the first measure; there were significant differences between the experiment and control groups in terms of engagement and affection. The results indicated that the emotional engagement scores of the participants in the experiment group $(\mathrm{Mdn}=20)$ were higher than the scores of those in the control group $(M d n=17,50) U=405,500, p=0,006 ; p>0.05$, effect size $(r)=-32)$. Behavioural engagement scores of the participants in the experiment group $(\mathrm{Mdn}=13,00)$ were higher than the scores of those in the control group $(\mathrm{Mdn}=8,00)$ $(\mathrm{U}=281,500, \mathrm{p}=0,000 ; \mathrm{p}>0.01$; effect size $(r)=-0,49)$. Cognitive engagement scores of the participants in the experiment group $(\mathrm{Mdn}=21,50)$ were higher than the scores of those in the control group ( $\mathrm{Mdn}=19,00), \quad(\mathrm{U}=305,500, \mathrm{p}=0,000 ; \mathrm{p}>0.01$; effect size $(\mathrm{r})$ $=-0,46)$. Furthermore, the positive affect scores of the participants in the experiment group $(\mathrm{Mdn}=36,50)$ were higher than the scores of those in the control group $(\mathrm{Mdn}=32,50) \quad(\mathrm{U}=408,500, \mathrm{p}=0,007 ; \mathrm{p}>0.05$; effect size $(\mathrm{r})=-32)$. The negative affect that was experienced in the experiment group $(\mathrm{Mdn}=12,00)$ were lower than the scores of those in the control group ( $M d n=17,00) \quad(U=376,000, p=0,002 ; p>0.01$ effect size $(r)$ $=-36$ ). These results indicate that students in the experimental group experience more positive and less negative affection; and also exhibit more behavioural, cognitive and 
emotional engagement than the students in the control group. Effects of the subjective well-being activities implemented in the experimental process: Eight subjective wellbeing increasing activities were used in the experimental process. The results were presented in Table-2. According to results, subjective well-being increasing activities affect of students' affection either moderately or highly. Just one activity which is named my flow list did not increase their positive affection although it diminished their negative affection.

Table 1: Descriptive statistics

\begin{tabular}{|c|c|c|c|}
\hline Scales & Groups & Test Condition & $M d n$ \\
\hline \multirow[t]{2}{*}{ Emotional engagement in general } & Experiment Group & Pre-test & 17.00 \\
\hline & Control Group & Pre-test & 17.00 \\
\hline \multirow[t]{2}{*}{ Behavioural engagement in general } & Experiment Group & Pre-test & 18.00 \\
\hline & Control Group & Pre-test & 17.50 \\
\hline \multirow[t]{2}{*}{ Cognitive engagement in general } & Experiment Group & Pre-test & 20.00 \\
\hline & Control Group & Pre-test & 19.00 \\
\hline \multirow[t]{2}{*}{ Positive Affection in general } & Experiment Group & Pre-test & 35 \\
\hline & Control Group & Pre-test & 34.50 \\
\hline \multirow[t]{2}{*}{ Negative Affection in general } & Experiment Group & Pre-test & 20 \\
\hline & Control Group & Pre-test & 19 \\
\hline \multirow[t]{2}{*}{ Positive Affection in general } & Experiment Group & Post-test & 38,00 \\
\hline & Control Group & Post-test & 32,50 \\
\hline \multirow[t]{2}{*}{ Negative Affection in general } & Experiment Group & Post-test & 13,00 \\
\hline & Control Group & Post-test & 17,00 \\
\hline \multirow{2}{*}{ Emotional engagement in the lesson } & Experiment Group & First measure & 20,00 \\
\hline & Control Group & First measure & 17,50 \\
\hline \multirow[t]{2}{*}{ Behavioural engagement in the lesson } & Experiment Group & First measure & 13,00 \\
\hline & Control Group & First measure & 8,00 \\
\hline \multirow{2}{*}{ Cognitive engagement in the lesson } & Experiment Group & First measure & 21,50 \\
\hline & Control Group & First measure & 19.00 \\
\hline \multirow[t]{2}{*}{ Positive Affection in the lesson } & Experiment Group & First measure & 36,50 \\
\hline & Control Group & First measure & 32,50 \\
\hline \multirow[t]{2}{*}{ Negative Affection in the lesson } & Experiment Group & First measure & 12,00 \\
\hline & Control Group & First measure & 17,00 \\
\hline \multirow[t]{2}{*}{ Emotional engagement in the lesson } & Experiment Group & Second measure & 21,50 \\
\hline & Control Group & Second measure & 7,00 \\
\hline \multirow[t]{2}{*}{ Behavioural engagement in the lesson } & Experiment Group & Second measure & 17,00 \\
\hline & Control Group & Second measure & 8,00 \\
\hline \multirow[t]{2}{*}{ Cognitive engagement in the lesson } & Experiment Group & Second measure & 22,00 \\
\hline & Control Group & Second measure & 9,00 \\
\hline \multirow[t]{2}{*}{ Positive Affection in the lesson } & Experiment Group & Second measure & 37,50 \\
\hline & Control Group & Second measure & 18,50 \\
\hline \multirow[t]{2}{*}{ Negative Affection in the lesson } & Experiment Group & Second measure & 14,50 \\
\hline & Control Group & Second measure & 24,00 \\
\hline \multirow[t]{2}{*}{ Midterm exam } & Experiment Group & - & 68,50 \\
\hline & Control Group & - & 59,00 \\
\hline \multirow[t]{2}{*}{ Final exam } & Experiment Group & - & 80,00 \\
\hline & Control Group & - & 72,00 \\
\hline \multirow[t]{2}{*}{ Application exam } & Experiment Group & - & 92,00 \\
\hline & Control Group & - & 84,00 \\
\hline \multirow[t]{2}{*}{ Follow up exam } & Experiment Group & - & 62,00 \\
\hline & Control Group & - & 49,50 \\
\hline
\end{tabular}

International Journal of Instruction, July $2015 \bullet$ Vol.8, No.2 
Table 2: Pre-Post Test Results for Affections

\begin{tabular}{|c|c|c|c|c|c|}
\hline Affection & Activities & Test Condition & $M d n$ & $z$ & Effect Size \\
\hline \multirow{16}{*}{$\begin{array}{l}\text { Positive } \\
\text { affection }\end{array}$} & \multirow{2}{*}{ Five things that made me happy in the past } & Pre-test & 33,50 & \multirow[t]{2}{*}{$-4,103 * *$} & \multirow[t]{2}{*}{$-0,48$} \\
\hline & & Post-test & 36,00 & & \\
\hline & \multirow[t]{2}{*}{ Gratitude } & Pre-test & 28,00 & \multirow[t]{2}{*}{$-3,338 * *$} & \multirow[t]{2}{*}{$-0,39$} \\
\hline & & Post-test & 34,00 & & \\
\hline & \multirow[t]{2}{*}{ Thankfulness } & Pre-test & 28,00 & \multirow[t]{2}{*}{$-3,568 *$} & \multirow[t]{2}{*}{$-0,42$} \\
\hline & & Post-test & 35,00 & & \\
\hline & \multirow{2}{*}{ The positive perception of myself } & Pre-test & 31,00 & \multirow[t]{2}{*}{$-2,902 * *$} & \multirow[t]{2}{*}{$-0,34$} \\
\hline & & Post-test & 37,00 & & \\
\hline & \multirow[t]{2}{*}{ Those supporting me in my life } & Pre-test & 34,50 & \multirow[t]{2}{*}{$-4,136^{* *}$} & \multirow[t]{2}{*}{$-0,49$} \\
\hline & & Post-test & 40,00 & & \\
\hline & \multirow[t]{2}{*}{ Happiness-oriented behaviours } & Pre-test & 34,50 & \multirow[t]{2}{*}{$-2,831 * *$} & \multirow[t]{2}{*}{-0.33} \\
\hline & & Post-test & 36,00 & & \\
\hline & \multirow[t]{2}{*}{ My flow list } & Pre-test & 29,00 & \multirow[t]{2}{*}{$-1,361$} & \multirow[t]{2}{*}{-} \\
\hline & & Post-test & 30,00 & & \\
\hline & \multirow[t]{2}{*}{ My future goals } & Pre-test & 26,00 & \multirow[t]{2}{*}{$-4,576 * *$} & \multirow[t]{2}{*}{$-0,54$} \\
\hline & & Post-test & 36,50 & & \\
\hline & \multirow[t]{2}{*}{ Five things that made me happy in the past } & Pre-test & 15,00 & \multirow[t]{2}{*}{$-3,842 * *$} & \multirow[t]{2}{*}{$-0,42$} \\
\hline & & Post-test & 13,00 & & \\
\hline & \multirow[t]{2}{*}{ Gratitude } & Pre-test & 17,00 & \multirow[t]{2}{*}{$-3,104 * *$} & $-0,37$ \\
\hline & & Post-test & 12,00 & & \\
\hline & Thankfulness & Pre-test & 17,00 & $-4,129 * *$ & $-0,49$ \\
\hline & & Post-test & 12,00 & & \\
\hline & The positive perception of myself & Pre-test & 15,00 & $-3,711 * *$ & $-0,44$ \\
\hline Negative & & Post-test & 12,00 & & \\
\hline affection & Those supporting me in my life & Pre-test & 13,50 & $-3,643 * *$ & $-0,43$ \\
\hline & & Post-test & 11,00 & & \\
\hline & Happiness-oriented behaviours & Pre-test & 13,00 & $-3,685^{* *}$ & -0.43 \\
\hline & & Post-test & 10,00 & & \\
\hline & My flow list & Pre-test & 15,00 & $-3,839 * *$ & $-0,42$ \\
\hline & & Post-test & 12,00 & & \\
\hline & My future goals & Pre-test & 18,00 & $-4,245^{* *}$ & $-0,50$ \\
\hline & & Post-test & 11,50 & & \\
\hline
\end{tabular}

$* \mathrm{p}<0.05, * * \mathrm{p}<0.01, \mathrm{n}=36$

\section{Findings are related to academic achievement}

In the experimental process, academic achievement such as midterm exam, final exam and application exam of both the students in the control and experimental groups were measured. The results were presented in Table-1. According to the Mann Whitney U test results of the midterm exam; there were not significant differences between the experimental and control groups $(U=487,000, p=0,070 ; p>0.05)$. However, final exam scores of the participants in the experimental group $(\mathrm{Mdn}=80,00)$ were higher than the scores of those in the control group $(M d n=72,00),(U=338,500, p=0,000 ; p>0.01$, effect size $(\mathrm{r})=-42)$.

Findings of effects that caused teaching process on general levels of students' subjective well-being

The effects of teaching process on students' positive and negative affection were measured with positive-negative affect scale. The results were presented in Table-1. According to the Mann Whitney $U$ test results; there were also significant differences between the experimental and control groups in terms of affection. The results indicated 
that the general positive effect scores of the participants in the experimental group $(\mathrm{Mdn}=38,00)$ were higher than the scores of those in the control group $(\mathrm{U}=319,500, \mathrm{p}=$ $0,108 ; \mathrm{p}>0.05$; effect size $(\mathrm{r})=-44)$. However, general negative effect scores of the participants in the experimental group $(\mathrm{Mdn}=13,00)$ were lower than the scores of those in the control group $(\mathrm{Mdn}=17,00),(\mathrm{U}=431,000, \mathrm{p}=0,014 ; \mathrm{p}>0.05$, effect size $(\mathrm{r})=-$ 0,29). The Wilcoxon Signed Rank test was used in order to compare students' pre-test and post-test scores in the experimental and control groups. The results were presented in Table-1. According to the results, the general positive effect post-test scores of the participants $(M d n=38,00)$ were higher than the pre-test scores $(M d n=35,00)$ of those in the experimental group $(\mathrm{z}=-3,621, \mathrm{p}=0,00 ; \mathrm{p}>0.01$; effect size $(\mathrm{r})=-43)$. However, the general negative effect post-test scores of the participants $(\mathrm{Mdn}=13,00)$ were lower than the pre-test scores of those $(\mathrm{Mdn}=19,00)$ in the experimental group. Furthermore, there was not a significant difference between the positive effect post-( $\mathrm{Mdn}=32,50)$ pre$(\mathrm{Mdn}=34,50)$ test scores of those in the control group $(\mathrm{z}=-1,187, \mathrm{p}=0,235 ; \mathrm{p}>0.05)$. Similarly, there was not a significant difference between the negative effect post$(\mathrm{Mdn}=17,00)$ pre- $(\mathrm{Mdn}=19,00)$ test scores of those in the control group $(\mathrm{z}=-1,549, \mathrm{p}=$ $0,121 ; \mathrm{p}>0.05)$.

\section{Qualitative Findings}

The qualitative evaluation of the teaching method was also conducted. The content analysis method was conducted through open-ended questions. The results of content analysis were shown in Table-3. Beside these evaluations, 32 students stated that there were no negative side of teaching method. Only four students considered that they were tired sometimes due to rewriting of engagement worksheets, and also making application homework. They got bored due to repeated measurement. Furthermore, 34 students did not give any suggestion. However, two students suggested that "we wanted to take more advanced information during the class hour" and "The Engagement worksheet should be shortened".

\section{Follow up study findings}

Midterm exam was used as a follows up study in order to examine the effects of teaching process. The results were presented in Table-1. According to the Mann Whitney $\mathrm{U}$ test results; there were significant differences between the experimental and control groups in terms of the results of follows up exam. The results indicated that follows up exams' scores of the participants in the experimental group $(\mathrm{Mdn}=62,00)$ were higher than the scores of those in the control group $(M d n=49,50)(U=394,500, p=$ $0,000 ; \mathrm{p}<0.01$; effect size $(\mathrm{r})=-34)$. Furthermore, the Wilcoxon Sign test was used in order to compare students' pre- and post-test scores in the experimental and control groups. According to the results, thefollow-up exam post-test scores of the participants $(M d n=62,00)$ were lower than the pre-test scores $(M d n=68,50)$ of those in the experimental group $(\mathrm{z}=-2,541, \mathrm{p}=0,011 ; \mathrm{p}<0.05$; effect size $(\mathrm{r})=-30)$. Similarly, the follow-up exam post-test scores of the participants $(M d n=49,50)$ were lower than the pre-test scores $(\mathrm{Mdn}=59,00)$ of those in the control group $(\mathrm{z}=-2,827, \mathrm{p}=0,005 ; \mathrm{p}<0.05$; effect size $(r)=-33)$. These results indicate that the students in the experimental group reduced their achievement less than the students in the control group. 
Table 3: Evaluations of the positive effects of teaching method by students

\begin{tabular}{|c|c|}
\hline $\begin{array}{c}\text { Positive side of } \\
\text { method }\end{array}$ & Sample sentences \\
\hline $\begin{array}{l}\text { Increased } \\
\text { learning }\end{array}$ & $\begin{array}{l}\text { I prepared myself for class that is so good for me. Then, when you lectured, learning of } \\
\text { the subject was strengthened. Other things that your lecture style characterized with } \\
\text { engagement and subjective well-being increasing activities, and construct map } \\
\text { supported the understanding of subjects. } \\
\text { We studied the subjects before we came to class, and we rewritten on the engagement } \\
\text { worksheet, this caused learning well. I do not think that I will forget the subjects. }\end{array}$ \\
\hline $\begin{array}{l}\text { Increased } \\
\text { engagement }\end{array}$ & $\begin{array}{l}\text { Attaching to a lesson is difficult but I attach to this lesson due to teaching method. } \\
\text { Our attention had been focused during the whole class hour thanks to this teaching } \\
\text { method. }\end{array}$ \\
\hline $\begin{array}{l}\text { Increased } \\
\text { subjective } \\
\text { well-being }\end{array}$ & $\begin{array}{l}\text { I think that the positive psychology activities relieved us from getting bored, and also } \\
\text { directed us for positives, since our subjective well-being levels were increased. } \\
\text { We remembered pleasant and enjoyable events again and again. This increased our } \\
\text { happiness. }\end{array}$ \\
\hline $\begin{array}{l}\text { Increased } \\
\text { awareness }\end{array}$ & $\begin{array}{l}\text { Teaching method supported that we realized ourselves and our affects. } \\
\text { I found some opportunities such as to compare my past with my future; to evaluate my } \\
\text { past experiences, plan my future. Thus, I realized that even the tiny things may influence } \\
\text { our lives. }\end{array}$ \\
\hline $\begin{array}{l}\text { Increased self- } \\
\text { regulation } \\
\text { Fostered } \\
\text { positive } \\
\text { relationships }\end{array}$ & $\begin{array}{l}\text { I found opportunity to regulate of myself. } \\
\text { Thanks to applications, our patience was increased. } \\
\text { Our friendships were strengthened by means of group activities that were done in the } \\
\text { classroom. }\end{array}$ \\
\hline
\end{tabular}

\section{DISCUSSION}

Studies in positive psychology indicate that the most important goals of education are to increase students' competence and abilities, and to develop their potentialities (Reschly and Ysseldyke, 1999). The other goal of education is to prevent students from pathological behavioural and cognitive patterns (Meyers and Nastasi (1999). Many study results show that high levels of engagement has been found related to higher level of learning and academic achievement, being open to new learning, using more learning strategies (Pintrich and De Groot, 1990); and also attaching the learning subject, being more resilient to difficulties and enjoying the study (Reschly and Christenson, 2006), having positive attitudes toward school and school related activities, exhibiting more academic achievement (Furlong and Christenson, 2008). On the other hand, study findings also show that students whose engagement levels are low do not show interest in classroom subjects, or do homework. They disrupt lessons, drop out, are absent and leave their education (Furrer and Skinner, 2003). Furthermore, some suggestions were also offered in order to increase students' engagement (Booker, 2006; Deci and Ryan, 2002; Furrer and Skinner, 2003). However, we need some teaching methods to increase students' engagement (Skinner and Pitzer, 2012). According to the quantitative and qualitative results of the present study, students not only engage in the lesson and demonstrate new learning but also increase their levels of subjective well-being by means of the teaching method. Thus, the present study makes an important contribution to relevant literature by improving a teaching method that gives an opportunity for increasing the levels of students' engagement, subjective well-being and also academic achievement. 
In literature it is found that students learning levels will increase in parallel with/to the increasing of students' engagement (Pintrich and De Groot, 1990). Moreover, positive psychology studies indicate that if students have experienced much more positive affection in the class, their capacities and perspectives will broaden, and also they will tailor the effects of negative past experiences. (Fredrickson, 2001; Grol, Koster, Bruyneel and Raedt, 2014; Hefferon and Boniwell, 2010). Additionally, the mediator role of teacher for students' engagement has been mentioned (Deci and Ryan, 2002; Furrer and Skinner, 2003; Skinner and Pitzer, 2012). Thus, to integrate these factors within a teaching method support to students' engagement, learning, positive experiences and academic achievement (Skinner and Pitzer, 2012). As a result of these empirical and theoretical considerations, the present study suggests the theoretically/empirically supported model illustrated below.

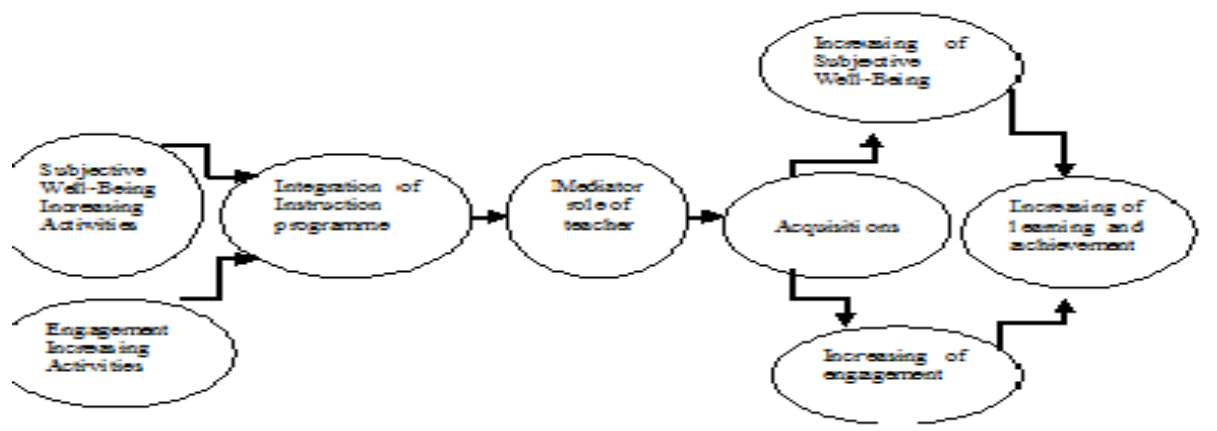

Figure 1: Theoretically/empirically supported model about increasing of learning and achievement

The results of the present study may be interpreted in accordance with self-concordance model. According to this model, if activities that were done by the students were suitable to them, students will be intrinsically motivated to these activities and be happy when they engage in activities. Some activities such as examples of my life's relation to the subject, e.g. how can I use things that I learnt in my own life and how can I use things that I learnt in my career, and also some subjective well-being increasing activities may be considered as activities that increase students' self-concordance. The results of the present study emphasize that the adaptation of teaching method takes time since the midterm results did not differentiate in that control and experimental groups. However final exam and follows up exam results differentiated in that control and experimental groups. Also, according to the results of measure of engagements, students showed better engagements at the eighth week than the fourth week. Some suggestions may be developed according to research results. The teaching method was carried out in a social science lesson rather than a 'hard' science lesson such as mathematics or physics. Thus, it might be carried out in science lessons in the future. Secondly, the study was carried out with university students. The implication may be carried out on high school or elementary school students. Thirdly, since the implementation process is extensive (working with 36 students, doing, many measures, giving feedback every 
week to students etc.), so, if teachers have many lessons, this implementation will be a heavy workload for those teachers. Thus, if teachers have fewer than 20 students, implementation can be easier. As a result, in the present study, the teaching method which is based on positive educational approach was developed and its effectiveness was investigated. The study findings indicate that the levels of subjective well-being and engagement of students may be increased through using this teaching method. Finally, their academic achievement and learning will increase.

\section{REFERENCES}

Ash, C., \& Huebner, E. S. (2001). Environmental events and life satisfaction reports of adolescents: A test of cognitive mediation. School Psychology International, 22, 320 336.

Baker, J. A. (1998). The social context of school satisfaction among urban, low-income, African-Americanstudents. School Psychology Quarterly, 13, 25-44.

Buss, D. M. (2000). The evolution of happiness. American Psychologist, 55, 15-23.

Booker, K. C. (2006). School belonging and the African- American adolescent: What do we know and where should we go? The High School Journal, 89, 1-7.

Cheng, H., \& Furnham, A. (2002). Personality, peer relations, and self-confidence as predictors of happiness and loneliness. Journal of Adolescence, 25, 327-339.

Davis, A. S., Kruczek, T., \& McIntosh, D. E. (2006). Understanding and treating psychopathology in schools: Introduction to the special issue. Psychology in the Schools, 43(4), 413-417.

Deci, E. L., \& Ryan, R. M. (Eds.). (2002). The handbook of self-determination research Rochester, NY: University of Rochester Press.

Diener, E. (1984). Subjective well-being. Psychological Buletin, 95(3), 542-575.

Eryllmaz, A. (2012). A model of subjective well-being for adolescents in high school. Journal of Happines Studies, 13(2), 275-289.

Eryılmaz, A. (2014). Üniversite öğrencileri için derse katılım ölçeklerinin geliştirilmesi. Uşak Üniversitesi Sosyal Bilimler Dergisi, 7(2), 203-214.

Fordyce, M. W. (1983). A program to increase happiness: Further studies. Journal of Counseling Psychology, 30, 483-498.

Fredrickson, B. L. (2001). The role of positive emotions in positive psychology: The broaden and-build theory of positive emotions. American Psychologist, 56, 218-226. doi:10.1037//0003- 066X.56.3.218.

Furrer, C., \& Skinner, E. (2003). Sense of relatedness as a factor in children's academic engagement and performance. Journal of Educational Psychology, 95, 148-162.

Furlong, M. J., \& Christenson, S. L. (2008). Engaging students at school with learning: A relevant construct for all students. Psychology in the Schools, 45, 365-368.

Gençöz, T. (2000). Positive and negative affect schedule: A study of validity and reliability. Turkish Journal of Psychology, 46, 19-26. 
Grol, M., Koster, E.H.W., Bruyneel, L., \& Raedt, R.D. (2014). Effects of positive mood on attention broadening for self-related information. Psychological Research, 78, 566-573.

Hefferon, K.,\& Boniwell, I. (2010). Positive Psychology. NewYork:McGraw Hill.

Hendirick, S.S. (2003). Understanding Close Relationships. London: Allyn \& Bacon, Incorporated

Loveless, T. (2006). How well are American students learning? With special sections on the nation's achievement, the happiness factor in learning, and honesty in state test scores. Washington, DC: The Brookings Institution.

Lyubomirsky, S., Sheldon, K. M., \& Schkade, D. (2005). Pursuing Happiness: The Architecture of Sustainable Change. Review of General Psychology, 9, 111-131.

Meyers, J., \& Nastasi, B.K. (1999). Primary prevention in school settings. In T. Gutkin \& C. Reynolds (Eds.), The handbook of school psychology (3rd ed.) (pp. 764-799). New York: Wiley.

Natriello, G. (1984). Problems in the evaluation of students and student from secondary schools. Journal of Research and Development in Education, 17, 14 - 24.

Nilson, L. (2010). Teaching at its best: A research---based resource for college instructors. (3rd ed). San Francisco: Jossey-Bass.

Pintrich, P.R. \& De Groot E. (1990). Motivational and self-regulated learning components of classroom academic performance. Journal of Educational Psychology, 82(1), 33-50

Reschly, A., \& Christenson, S. L. (2006). Research leading to a predictive model of dropout and completion among students with mild disabilities and the role of student engagement. Remedial and Special Education, 27, 276 - 292.

Reschly, D.J., \& Ysseldyke, J.E. (1999). Paradigm shift: The past is not the future. In T. Gutkin \& C. Reynolds (Eds.), The handbook of school psychology (3rd ed.) (pp. 3-20). New York: Wiley.

Scheerens, J., \& Bosker, R. J. (1997). The foundations of educational effectiveness. Oxford: Pergamon.

Seligman, M. 2002 Authentic happiness. New York: Free Press.

Skinner, E. A., Furrer, C., Marchand, G., \& Kindermann, T. (2008). Engagement and disaffection in the classroom: Part of a larger motivational dynamic? Journal of Educational Psychology, 100, 765-781

Skinner, E. A., \& Pitzer, J. (2012). Developmental dynamics of engagement, coping, and everyday resilience. In S. Christenson, A. Reschly, \& C. Wylie (Eds.), The Handbook of Research on Student Engagement (pp. 21-45). New York: Springer Science. 


\section{Turkish Abstract}

Pozitif Psikoloji Sınıfta: Öznel İyi Oluşu Artırma Stratejileri ve Derse Katılımı Artıran Stratejiler Temelli Geliştirilen Bir Öğretim Yönteminin Etkililiği

$\mathrm{Bu}$ çalışmanın amacı üniversite öğrencileri için geliştirilen öznel iyi oluşu ve katılımı artırıcı etkinlikler üzerine temellendirilmiş bir öğretim yönteminin etkililiğini incelemektir. Çalışma karma metod olarak tasarlanmıştır. Bu metodun en önemli özelliğinin deney ve kontrol gruplu ön test, son test ve ekleri içeren bir deneysel metod olması söylenebilir. Ayrıca, çalışmada nitel metod da kullanılmıştır. 72 üniversite öğrencisi (deney grubunda 14 erkek-22 kadın ve kontrol grubunda 10 erkek-26 kadın) çalışmaya katılmıştır. Verilerin toplanmasında Pozitif ve Negatif Etkiler Ölçeği, Bağlılık Ölçeği ve akademik testler kullanılmıştır. Çalışma bu öğretim metodunun kullanılmasının hem öğrencilerin akademik başarılarını hem de öznel iyi oluşlarını artıracağını göstermiştir.

Anahtar Kelimeler: üniversite öğrencileri, derse katılım, öznel iyi oluş, öğretmen, öğrenci

\section{French Abstract}

La Psychologie Positive dans la Classe: l'Efficacité d'une Méthode Enseignante Basée sur Bien-être Subjectif et Engagement Augmentant Activités

Le but de l'étude présente est l'examinent l'efficacité d'une méthode enseignante qui est basée sur le bien-être subjectif des activités croissantes et l'engagement des activités croissantes, a été développée pour des étudiants universitaires dans l'étude présente. La méthode de l'étude présente est une méthode mixte. Ainsi, on en a considéré la caractéristique la plus importante la méthode expérimentale qui inclut le pré-test, le post-test et donne suite au design avec expérimental et des groupes témoins. Aussi, la méthode qualitative a été conduite dans l'étude présente. 72 étudiants universitaires (14 mâles et 22 femelles dans le groupe expérimental; 10 mâle et 26 femelle dans le groupe témoin) ont participé à cette étude. L'échelle d'Affect Positive et Négative, des Échelles d'Engagement, les tests d'accomplissement universitaires ont été utilisés pour rassembler des données. Les découvertes d'étude indiquent les niveaux de bien-être subjectif, l'engagement, l'apprentissage, l'accomplissement universitaire d'étudiants peut être augmenté par l'utilisation de cette méthode d'enseignement.

Mots Clés: étudiants universitaires, engagement, bien-être subjectif, enseignement, étudiants

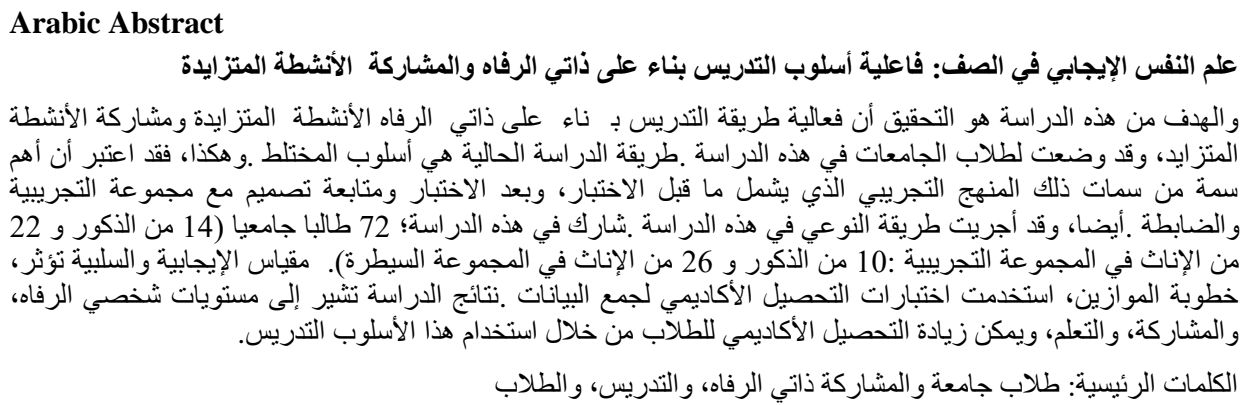

